\section{LINKAGE BETWEEN THE Rpg1 GENE FOR STEM RUST RESISTANCE AND THE $f 5$ LOCUS ON BARLEY CHROMOSOME 1}

\author{
Yue Jin, ${ }^{*}$ Brian J. Steffenson, and Jerome D. \\ FRANCKOWIAK
}

\begin{abstract}
Linkage studies can expedite the transfer of agronomically important genes in breeding programs. A study was condacted to determine the linkage relationship between loci segregating for stem rust (Puccinia graminis Pers.:Pers. f. sp. tritici Eriks. \& E. Henn.) resistance (Rpg1) and a chlorina mutant (f5), and to confirm the linkage among Rpgl, brl (brachytic) and $f_{\mathrm{c}}$ (chlorina seedling). 'Bowman' barley (Hordeum vulgare L.) was crossed to genetic stocks possessing $b r 1, f_{c}$, and $f 5$, respectively. Estimates of linkage distances were $9.6 \pm 1.4 \%$ between $R p g 1$ and $b r 1,13.6 \pm 1.8 \%$ between $R p g 1$ and $f_{c}$, and 25.9 $\pm 2.6 \%$ between $R p g 1$ and $f 5$. The linkage between $R p g 1$ and $f 5$ was established.
\end{abstract}

$\mathrm{T}$ HE Rpg1 (or T) gene (9) in barley confers resistance to a number of pathotypes (races) of the wheat stem rust pathogen $(3,4,15)$. This gene has protected barley from significant losses due to stem rust since the release of 'Kindred' barley in 1942. Nearly every barley cultivar grown in the North Central region of the USA has been bred with Rpg1. Although a pathotype (Pgt-QCC) virulent to Rpgl was recently detected in the Great Plains $(5,10)$, the gene is still effective against some of the most prevalent pathotypes in the North American wheat stem rust population.

Genotypes possessing Rpg1 can be easily identified in the field because they exhibit a low level of rust infection and primarily incompatible infection responses. The evaluation of resistance in the seedling stage, however, has been difficult because most barley genotypes display mesothetic reactions (mixture of compatible and incompatible infection types on the same leaf) to many wheat stem rust pathotypes $(4,6,8,15)$. Pathotype MCC was found to be valuable in differentiating genotypes with Rpg1 (14). Linkage between Rpg1 and brl (brachytic), $f_{c}$ (chlorina seedling) (2), wx (waxy endosperm) (12), and Run1 [resistance to Ustilago tritici (Pers.) Rostr. Syn Ustilago nuda (C.N. Jersen) Rostr.] $(1,11)$ were previously studied. Based on these studies, Rpgl was placed in the chromosome 1 linkage group (7). A chlorina-plant mutant gene, $f 5$, was located on the short arm of chromosome 1 (16); however, the exact location of this locus is not known. This study was conducted to determine the linkage relationship between the Rpgl and f5 loci, and to corroborate the linkage relationships between Rpgl, and $b r l$, and $f_{\mathrm{c}}$.

\section{Materials and Methods}

Three $F_{2}$ populations were developed from crosses between Bowman (PI 483237) barley, which possesses Rpg1, and the genetic marker stocks of DWS 1132, BGS 002, and BGS 018,

Y. Jin and B.J. Steffenson, Dep. of Plant Pathology; and J.D. Franckowiak, Dep. of Crop and Weed Sciences, North Dakota State Univ., Fargo, ND 58105. Received 8 May 1992. *Corresponding author.

Published in Crop Sci. 33:642-643 (1993). which possess $b r l, f_{c}$, and $f 5$, respectively. For all three crosses, the genes were tested in the coupling phase. The morphological markers used in this study were readily recognizable at the seedling stage of growth. Both $f 5$ and $f_{\mathrm{c}}$ are chlorina mutants, and the homozygous recessive genotype of each locus produces light green seedlings; however, $f_{\mathrm{c}}$ chlorina seedlings change to green after the first leaf stage. Plants exhibiting the chlorina phenotype were tagged at the first leaf stage. The homozygous genotype of $b r l$ can be recognized by smaller and broader leaves at the seedling stage.

Seedlings of parental and $F_{2}$ plants from each cross were evaluated for their infection types to pathotype MCC of $P$. graminis f. sp. tritici (culture A-5), provided by Dr. J.D. Miller (Northern Crop Sciences Laboratory, USDA-ARS, Fargo, ND). $F_{1}$ plants were not available for this test. The ITs were assessed using the system of Miller and Lambert (6) in which IT 0; indicates necrotic flecks without visible sporulation, IT 1 indicates small sporulating pustules surrounded by distinct necrosis, IT 2 and IT 3 indicate progressively larger pustules with or without necrosis, and IT 4 describes large pustules. Most genotypes homozygous for Rpg1 exhibit ITs ranging from 0 ; to 21 and those without the gene, 23- to 33- (14). In a preliminary experiment, Bowman exhibited ITs ranging from 0 ; to 21 , but ITs of 0 ; and 1 predominated. The ITs on parents possessing the recessive allele for stem rust susceptibility ranged from 23- to $33+$. In the classification of $F_{2}$ seedlings, plants with ITs of 23- or higher were considered susceptible (homozygous recessive for Rpg1), and those with ITs of $0 ; 0 ; 1,12$ or 21 were considered resistant (homozygous or heterozygous for Rpg1).

Seed was sown in super-cell containers (Stuewe \& Sons, Corvallis, OR) filled with No. 1 Sunshine mix (Fisons Horticulture, Vancouver, $\mathrm{BC}$ ), and grown at 21 to $25^{\circ} \mathrm{C}$ in the greenhouse. Plants were inoculated with pathotype MCC $7 \mathrm{~d}$ after planting when the primary leaves were fully expanded. Inoculations were made with $6.0 \mathrm{mg}$ urediniospores $\mathrm{mL}^{-1}$ Soltrol 170 oil (Phillips Petroleum Co., Borger, TX) applied at a rate $\approx 1 \mu \mathrm{L}$ oil per plant. After inoculation, plants were incubated in a chamber where the humidity was maintained near saturation for $16 \mathrm{~h}$ at $21{ }^{\circ} \mathrm{C}$ in the dark. The leaf surfaces were kept moist by periodic misting (32 s misting every $16 \mathrm{~min}$ ) from an ultrasonic humidifier (13). After the mist period, the plants were exposed to sunlight in a greenhouse and allowed to dry slowly. The plants were subsequently incubated in a growth chamber at 25 to $28^{\circ} \mathrm{C}$ with a photoperiod of $12 \mathrm{~h}$ (115-W fluorescent bulbs emitting between 132.2 to 144.4 $\mu$ mol photon $\mathrm{m}^{-2} \mathrm{~s}^{-1}$ ). The ITs on each plant were assessed $12 \mathrm{~d}$ after inoculation. The chi-squared and maximum-likelihood methods were used to test the independence of segregation in the $F_{2}$ populations, and to estimate the recombination fraction, respectively.

\section{Results and Discussion}

The observed frequencies of each phenotypic class, calculated chi-squared values for independence of segregation, and maximum-likelihood estimates of recombination fractions for the three crosses are given in Table 1. All calculated chi-squared values for testing single pairs of genes were not significant, with the exception of the cross involving Rpgl and $f 5$. In this cross, the number of susceptible plants was slightly higher than expected. This may have resulted from misclassification of the stem rust infection type.

The calculated values for linkages in all three crosses were significant, indicating linkage relationships between Rpg1 and the three mutant loci. The maximumlikelihood estimate of the linkage distance was 25.9 $\pm 2.6 \%$ between $R p g 1$ and $f 5$. The estimated distances

Abbreviations: cM, centimorgan; IT, infection type. 
Table 1. Segregation ratios of $F_{2}$ plants from barley crosses involving $R p g 1$ and three morphological markers br $1, f_{c}$, and $f 5$ on chromosome 1.

\begin{tabular}{|c|c|c|c|c|c|c|c|c|c|c|}
\hline \multicolumn{2}{|c|}{ Genes tested } & \multicolumn{4}{|c|}{$\begin{array}{l}\text { Number of } F_{2} \text { plants } \\
\text { in each phenotype } \dagger\end{array}$} & \multicolumn{3}{|c|}{ Chi-square test $\ddagger$} & \multirow{2}{*}{$\begin{array}{l}\text { Recomb- } \\
\text { ination } \\
\text { fraction§ }\end{array}$} & \multirow[b]{2}{*}{ SE } \\
\hline $\bar{A}$ & $\boldsymbol{b}$ & $\overline{A B}$ & $A b$ & $a B$ & $\overline{a b}$ & $X_{A}^{2}$ & $\overline{X_{B}^{2}}$ & $\overline{X_{2}^{2}}$ & & \\
\hline $\begin{array}{l}\text { Rpg1 } \\
\text { Rpg1 } \\
\text { Rpg1 }\end{array}$ & $\begin{array}{l}b r 1 \\
f_{c} \\
f_{5}\end{array}$ & $\begin{array}{l}332 \\
303 \\
246\end{array}$ & $\begin{array}{l}26 \\
22 \\
50\end{array}$ & $\begin{array}{l}20 \\
34 \\
52\end{array}$ & $\begin{array}{r}110 \\
82 \\
71\end{array}$ & $\begin{array}{l}0.70 \\
0.40 \\
4.24\end{array}$ & $\begin{array}{l}2.14 \\
0.47 \\
3.36\end{array}$ & $\begin{array}{r}319.18 \\
192.02 \\
88.90\end{array}$ & $\begin{array}{r}9.6 \\
13.6 \\
25.9\end{array}$ & $\begin{array}{l}1.4 \\
1.8 \\
2.6\end{array}$ \\
\hline
\end{tabular}

† Phenotype $A B$ represents $F_{2}$ plants with dominant alleles at both loci. The double recessive genotype (aabb) produces the phenotype of $a b$. $\ddagger X_{0.05}^{2}(1)=3.84$ and $X_{0.01}^{2}(1)=6.63$. Expected ratio for $X^{2}$-testing is 3:1 for genes $A\left(X_{A}^{2}\right)$ and $B\left(X_{B}^{2}\right)$, and $9: 3: 3: 1$ for linkage $\left(X_{D}^{2}\right)$.

$\$$ Recombination fraction calculated using the method of maximum likelihood.

were $9.6 \pm 1.4 \%$ between $R p g 1$ and $b r 1$, and $13.6 \pm$ $1.8 \%$ between $R p g 1$ and $f_{\mathrm{c}}$, which were slightly smaller than the previously reported values of 12.6 and $16.7 \%$, respectively, (2). Unpublished data from the North American Barley Genome Mapping Project indicate that $R p g 1$ is very close $(\approx 3 \mathrm{cM})$ to a subtelomeric marker (Tells) on the short arm of chromosome 1 . Therefore, $f 5$ is postulated to be proximal in relationship to Rpg1, $b r 1$, and $f_{c}$. This putative location of $f 5$ is in conflict with Tsuchiya (17), who placed the $f 5$ locus at the distal end of the short arm of chromosome 1 . The exact location of $f 5$ can only be resolved with further linkage analysis.

\section{References}

1. Andrews, J.E. 1956. Inheritance of reaction to loose smut, Ustilago nuda, and stem rust, Puccinia graminis tritici, in barley. Can. J. Agric. Sci. 36:356-370.

2. Brookins, W.W. 1940. Determination of linkage relationship of factors differentiating reaction to stem rust in barley crosses. Ph.D. diss., Univ. of Minnesota, St. Paul.

3. Immer, F.R., J.J. Christensen, and W.Q. Loegering. 1943. Reaction of strains and varieties of barley to many physiologic races of stem rust. Phytopathology 33:253-254.

4. Jedel, P.E., D.R. Metcalfe, and J.W. Martens. 1989. Assessment of barley accessions PI 382313, PI 382474, PI 382915 , and PI 382976 for stem rust resistance. Crop Sci. 29:1473-1477.

5. Martens, J.W., K.M. Dunsmore, and D.E. Harder. 1989. Incidence and virulence of Puccinia graminis in Canada on wheat and barley 1988. Can. J. Plant Path. 11:424-430.
6. Miller, J.D., and J.W. Lambert. 1955. Variability and inheritance of reaction of barley to race 15B of stem rust. Agron. J. 47:373-377.

7. Nilan, R.A. 1964. The cytology and genetics of barley 19511962. Monographic suppl. no. 3. Vol. 32. No. 1. Washington State Univ. Press, Pullman, WA.

8. Patterson, F.L., R.G. Shands, and J.G. Dickson. 1957. Temperature and seasonal effects on seedling reactions of barley varieties to three races of Puccinia graminis f. sp. tritici. Phytopathology 47:395-402.

9. Powers, L., and L. Hines. 1933. Inheritance of reaction to stem rust and barbing of awns in barley crosses. J. Agric. Res. 46:1121-1129.

10. Roelfs, A.P., D.H. Casper, D.L. Long, and J.J. Roberts. 1991. Races of Puccinia graminis in the United States in 1989. Plant Dis. 75:1127-1130.

11. Shands, R.G. 1946. An apparent linkage of resistance to loose smut and stem rust in barley. J. Am. Soc. Agron. 38:690692.

12. Shands, R.G. 1959. The relationship of stem rust $(T t)$ and starch $(\boldsymbol{W} x \boldsymbol{w})$ characters to malt amylases in F3 families of a barley cross. Barley Newsl. 3:9.

13. Steffenson, B.J., and T. Fetch. 1990. An improved technique for creating and maintaining leaf wetness by use of ultrasonic humidifiers. Phytopathology 80:1059 (Abstract).

14. Steffenson, B.J., J.D. Miller, and Y. Jin. 1991. Detection of the $T$ gene for resistance to Puccinia graminis f. sp. tritici in barley seedlings. Phytopathology 81:1229 (Abstract).

15. Steffenson, B.J., R.D. Wilcoxson, and A.P. Roelfs. 1985. Resistance of barley to Puccinia graminis f. sp. tritici and Puccinia graminis f. sp. secalis. Phytopathology 75:11081111.

16. Tsuchiya, T. 1972. Cytogenetics of telotrisomics in barley. Barley Genet. Newsl. 2:93-98.

17. Tsuchiya, T. 1986. Current linkage maps of barley. Barley Genet. Newsl. 16:40-43. 